\title{
Gas chromatographic determination of methoxyacetic and ethoxyacetic acid in urine
}

\author{
D GROESENEKEN, E VAN VLEM, H VEULEMANS, AND R MASSCHELEIN \\ From the Laboratorium voor Arbeidshygiëne en -toxicologie, Afdeling Arbeids-en Verzekeringsgeneeskunde, \\ $K U$ Leuven, B-3000 Leuven, Belgium
}

ABSTRACT Methoxyacetic acid (MAA) and ethoxyacetic acid (EAA), the major metabolites of, respectively, ethylene glycol monomethyl ether and ethylene glycol monoethyl ether and their acetates, are determined by gas chromatography after extraction from urine and methylation using 2 -furoic acid (2-FA) as an internal standard. The mean recoveries $(n=30)$ from urine of MAA, EAA, and 2-FA are $31.4 \pm 7.0 \%, 62.5 \pm 13.4 \%$, and $58.4 \pm 8.7 \%$, respectively. The recoveries decreased ( $p<0.001)$, however, as the total amount of acids increased. Standard curves for MAA and EAA in urine are presented. The detection limits of MAA and EAA are 0.15 and $0.07 \mathrm{mg} / 1$. Intra-assay variation for MAA and EAA was $6.0 \pm 2.5 \%$ and $6.4 \pm 2.8 \%$ and inter-assay variation was $6 \cdot 2 \pm 2 \cdot 2 \%$ and $8.9 \pm 2 \cdot 4 \%$. When volunteers were exposed to air containing ethylene glycol monoethyl ether $\left(20 \mathrm{mg} / \mathrm{m}^{3}\right)$, urinary concentration of EAA rose significantly one hour after the exposure period $(2.39 \pm 1.03 v \leqslant 0.07 \mathrm{mg} / 1, t=5.2, \mathrm{p}<0.005)$.

Glycol ethers and their acetates are used widely in industrial work and the toxicological publications relating to them have recently been reviewed by Rowe and Wolf. ${ }^{1}$

The industrial exposure to vapours of organic solvents may be estimated by analysis of air samples. Since intoxication can occur as the result not only of inhalation of the vapours but also by skin absorption, analysis of urinary metabolites is a useful complement. Recent studies on the metabolism of ethylene glycol monoalkyl ethers in rats and dogs have shown that their respective alkoxyacetic acids are the major urinary metabolites. ${ }^{2-5}$ Moreover, the toxicological properties of methoxyacetic acid (MAA) are remarkably similar to ethylene glycol monomethyl ether (EGME) and the adverse effects of EGME in rats are probably the results of in vivo bioactivation of EGME to MAA. ${ }^{6}$

These findings suggest that the urinary excretion of the alkoxyacetic acids may be a useful indication of human exposure to ethylene glycol ethers. Therefore, we have developed a rapid, selective, and sensitive

Accepted 13 May 1985 method for the determination of MAA and ethoxyacetic acid (EAA), the metabolities of ethylene glycol monomethyl ëther and ethylene glycol monoethyl ether and their acetates, in the urine.

\section{Methods}

REAGENTS

MAA and EAA were obtained from MerckSchuchardt (Hohenbrunn, FRG). 2-Furoic acid (EGA-chemie, Steinheim, Albuch, FRG) was used as 3 an internal standard. Spectrograde methylene chloride $\left(\mathrm{CH}_{2} \mathrm{Cl}_{2}\right)$ was purchased from Burdick and Jackson (Muskegon, Michigan, USA). All other chemicals used were of analytical grade.

PREPARATION OF THE SAMPLES

Standards or urine samples were adjusted to $\mathrm{pH}$ 8-8.5 N with a few drops of $5 \mathrm{M} \mathrm{KOH}$ before analysis. To $1 \mathrm{ml}$ of sample $50 \mu \mathrm{g}$ of 2 -furoic acid (2-FA) in $100 \mu \mathrm{l}$ of $\stackrel{\mathrm{N}}{\mathrm{N}}$ water was added. The sample was than lyophilised. $\omega$ The dry residue was taken up in $10 \mu$ l of concentrated $\widetilde{\sigma}$ hydrochloric acid and $1 \mathrm{ml}$ of $\mathrm{CH}_{2} \mathrm{Cl}_{2}$ and mixed 0 vigorously during $2 \times 15$ seconds. After this time $\mathbb{\Phi}$ $500 \mu \mathrm{l}$ of the organic layer was transferred to a vial $\stackrel{?}{?}$ and $150 \mu \mathrm{l}$ of a solution of diazomethane in $\mathrm{CH}_{2} \mathrm{Cl}_{2} \underset{T}{\mathrm{~T}}$ was added to esterify the acids. After the excess of $\frac{P}{\mathbb{D}}$ diazomethane was removed, the vials were capped $\cong$ 
and stored for further analysis.

Diazomethane was prepared immediately before use in a millimole size generator by adding $600 \mu \mathrm{l}$ of $20 \% \mathrm{KOH}$ in methanol to $200 \mathrm{mg}$ of $N$-methyl- $N$ nitroso-p-toluenesulphonamide according to Fales et al. ${ }^{7}$

\section{GAS CHROMATOGRA PHY}

The methylated acids were analysed with a HewlettPackard 5890 A gas chromatograph equipped with a flame ionisation detector and a CP WAX 57 CB, WCOT fused silica column $(25 \mathrm{~m} \times 0.33 \mathrm{~mm} \mathrm{ID,} 0.22$ $\mu \mathrm{m}$ film thickness). The oven temperature was programmed from $50^{\circ}$ to $187^{\circ} \mathrm{C}$ at a rate of $12.5^{\circ} \mathrm{C} / \mathrm{min}$ and maintained at $187^{\circ} \mathrm{C}$ for a further 1.5 minutes. The injector and detector were both kept at $230^{\circ} \mathrm{C}$. The injection volume was $5 \mu \mathrm{l}$ and the splitting ratio was 10:1. The flow rate of helium carrier gas was 1 $\mathrm{ml} / \mathrm{min}$. Retention times of MAA, EAA, and 2-FA were $4.52 \pm 0.02 \mathrm{~min}, 4.96 \pm 0.02 \mathrm{~min}$, and $8.48 \pm$ $0.02 \mathrm{~min}$ (fig 1).

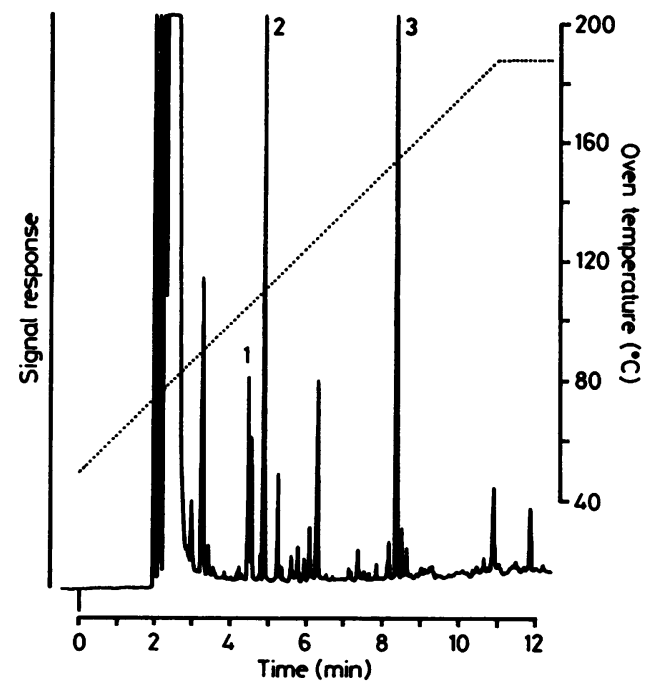

Fig 1 Gas chromatography of (1) methoxyacetic acid, (2) ethoxyacetic acid, and (3) 2-furoic acid extracted from urine and methylated with diazomethane. Column: $C P$ WAX 57 CB, WCOT fused-silica $(25 \mathrm{~m} \times 0.33 \mathrm{~mm} \mathrm{ID;}$ $0.22 \mu \mathrm{m}$ film thickness); carrier gas: helium (1 $\mathrm{ml} / \mathrm{min})$; injection volume $5 \mu \mathrm{l}$; split ratio 10:1; detector: FID. Oven temperature programme is presented in dotted lines.

\section{Results}

RECOVERY OF THE EXTRACTION PROCEDURE MAA and EAA were added to urine in concentrations ranging from 5 to $50 \mathrm{mg} / \mathrm{l}$ and analysed as described. Peak areas of the acids and 2-FA were compared with methylated standards in $\mathrm{CH}_{2} \mathrm{CL}_{2}$.

The mean recoveries $( \pm$ SD) of MAA, EAA, and 2-FA were $(n=30) 31.4 \pm 7.0 \%, 62.5 \pm 13.4 \%$, and $58.4 \pm 8.7 \%$. The recoveries of MAA, EAA, and 2-FA decreased $(F \geqslant 28 ; p<0.001)$ as the total amount of acids increased. This negative relation may partly explain the large overall variations observed in the recoveries. The recoveries of MAA and EAA, however, are positively correlated $(r \geqslant 0.86 ; p<$ 0.001 ) with the recovery of 2-FA.

The lower recovery of MAA may be due to the high ratio of partition between water and organic solvents. $^{8}$ The recoveries were optimal when urine was first adjusted to $\mathrm{pH} \mathrm{8-8.5}$ and decreased slowly when the $\mathrm{pH}$ was out of this range.

\section{STANDARD CUR VE AND DETECTION LIMIT}

Standard curves for MAA and EAA in urine were set up in a range of $1-100 \mathrm{mg} / \mathrm{l}$. Data were expressed as the response (area \%) relative to the internal standard (fig 2).

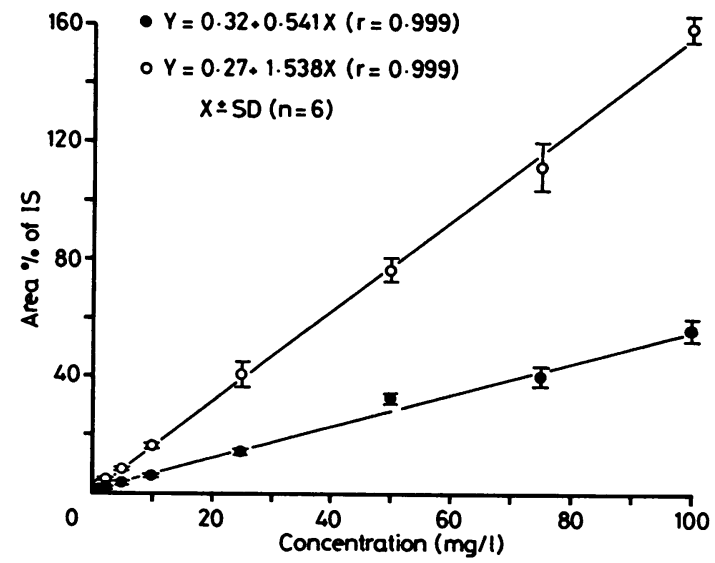

Fig 2 Standard curves of (O) methoxyacetic acid and (O) ethoxyacetic acid in urine. Data are means of six determinations $\pm S D$.

Despite the variations of the recoveries, the standard curves are linear $(r=0.99)$ in the range considered and may be written as:

$y=0.32+0.541 x$ for MAA and

$y=0.27+1.538 x$ for EAA.

The lower recoveries of MAA and EAA in the higher concentration range are compensated by a lower recovery of the internal standard.

At a signal to noise ratio of 5 , the lowest detectable amount on column was $34 \mathrm{pg}$ for MAA and $32 \mathrm{pg}$ for EAA. When extraction recovery, injection volume $(5 \mu \mathrm{l})$, and starting volume of urine $(1 \mathrm{ml})$ are taken into account, the procedure is capable of quantitating $0.15 \mathrm{mg} / 1 \mathrm{MAA}$ and $0.07 \mathrm{mg} / \mathrm{l} \mathrm{EAA}$. 


\section{ANALYTICAL RECOVERY}

Urine samples containing MAA and EAA in concentrations ranging from 5 to $50 \mathrm{mg} / \mathrm{l}$ were analysed 15 times on three separate days (table 1). Intra-assay variation from MAA and EAA was $6.0 \pm 2.5 \%$ and $6.4 \pm 2.8 \%$ and inter-assay variation was $6 \cdot 2 \pm 2 \cdot 2 \%$ and $8.9 \pm 2.4 \%$.

Table 1 Analytical recovery of $M A A$ and $E A A$ from urine. (Amounts found are means of 15 determinations $\pm S D$ on three separate days)

\begin{tabular}{lc}
\hline Amount added $(\mathrm{mg} / \mathrm{l})$ & Amount found $(\mathrm{mg} / \mathrm{l})$ \\
\hline$M A A$ & \\
5 & $5.7 \pm 1.6$ \\
25 & $25.8 \pm 1.6$ \\
50 & $50.2 \pm 2.2$ \\
& \\
$E A A$ & \\
5 & $5.5 \pm 0.6$ \\
25 & $25.1 \pm 3.2$ \\
50 & $49.0 \pm 3.9$ \\
\hline
\end{tabular}

\section{APPLICATION}

To test whether the method is able to detect EAA in urine of man after exposure to ethylene glycol monoethyl ether (EGEE), five healthy male volunteers (ages $24 \pm 4$ years) were exposed at rest to air containing $20 \mathrm{mg} / \mathrm{m}^{3}$ EGEE during $4 \times 50$ minutes, separated by a 10 minute break. The concentration of EGEE in the air chosen is compatible with the threshold limit value for industrial exposures. ${ }^{9}$ Detailed information about the method used for controlled exposure to organic vapours may be found elsewhere. ${ }^{10}$

The volunteers collected their urine immediately before and exactly one hour after the experimental period. The urine samples were analysed for the presence of EAA (table 2).

Before exposure, a small peak eluting at the same retention time as EAA was detected in the chromatogram. We were not able to identify this peak, but assuming it was EAA only, concentrations near or less than the detection limit could be calculated. Only one subject had a higher starting concentration

Table 2 Urinary concentration of EAA before and after exposure to ethylene glycol monoethyl ether $\left(20 \mathrm{mg} / \mathrm{m}^{3}\right)$

\begin{tabular}{lll}
\hline \multirow{2}{*}{$\begin{array}{l}\text { Subject } \\
\text { No }\end{array}$} & \multicolumn{2}{c}{ Concentration of EAA in urine $(\mathrm{mg} / \mathrm{l})$} \\
\cline { 2 - 3 } & Before exposure & After exposure \\
\hline 1 & 0.41 & 3.87 \\
2 & $\mathrm{ND}$ & 2.48 \\
3 & $\leqslant 0.07$ & 1.86 \\
4 & $\leqslant 0.07$ & 1.08 \\
5 & $\leqslant 0.07$ & 2.68 \\
Mean \pm SD & - & $2.39 \pm 1.03^{*}$ \\
\hline N $<0.005$. &
\end{tabular}

Groeseneken, van Vlem, Veulemans, and Masschelein $\bar{\alpha}$

$(0.41 \mathrm{mg} / \mathrm{l})$. On specific questioning, he stated that he might have been exposed to EGEE during his professional activity some days before the experiment.

One hour after the exposure period, the concentration of EAA in urine was significantly higher than $\frac{0}{0}$ the baseline values $(2.39 \pm 1.03 v \leqslant 0.07 \mathrm{mg} / 1 ; t=5.2$, $\mathrm{p}<0.005)$.

\section{Discussion}

Since the identification of alkoxyacetic acids as the major metabolites of ethylene glycol monoalkyl ethers ${ }_{\sigma}^{\omega}$ in rats and dogs by several authors ${ }^{2-5}$ the urinary $O$ excretion of these acids could be used as a biological $\frac{\mathbb{}}{3}$ monitor of exposure to ethylene glycol ethers. Nevertheless, the published methods available for mea- $\omega$ suring the excretion of alkoxyacetic acids were mostly os qualitative. Therefore, we have developed a rapid ${ }^{N}$ selective and sensitive method for determining MAA and EAA in the urine.

Before analysis the acetic acids and the internal standard are extracted from the urine. A preceding lyophilisation of the urine sample turned out to be necessary to increase the recovery of the extraction $\vec{\varphi}$ procedure. The lyophilisation was performed at $\mathrm{pH}$ $>7.5$ to yield quantitatively the potassium salts since losses of the free acids were observed at lower pHO values. When the $\mathrm{pH}$ was higher than 9 , however, recovery of the acetic acids and of the internal stan-o dard gradually decreased. This could be due to the $\frac{\otimes}{\varnothing}$ limiting quantity of concentrated $\mathrm{HCl}$ to acidify the $\propto$ medium just before the extraction. The use of greater $\overrightarrow{\overrightarrow{0}}$ quantitaties of $\mathrm{HCl}$, however, was impossible because 3 a decrease of recovery due to an altered volume ratio between aqueous and organic phases was observed. Taken into account these observations a $\mathrm{pH}$ range of $O$ 8-8.5 turned out to be optimal.

The recoveries of the acetic acids are acceptable and are positively correlated with the recovery of the inter 3 . nal standard. The recovery of the internal standard $\delta$ compensates for the variation of the absolute recoveries of the individual samples. The standard curveso are linear in the range of $1-100 \mathrm{mg} / \mathrm{l}$ for both MAA and EAA, and the method can detect concentrationso as low as $0.15 \mathrm{mg} / \mathrm{l}$ for MAA and $0.07 \mathrm{mg} / \mathrm{l}$ for EAA. The day to day variation is small and of the sameos order of magnitude as the intra-assay variation for $N$ both MAA and EAA.

The preliminary results of a study of the excretion of the metabolites in non-exposed and in exposed individuals suggest that EAA could be a specific and $\stackrel{\circ}{\circ}$ sensitive parameter for monitoring workers' exposures to EGEE.

We are indebted to Dr W Goossens from the department of haematology for performing the lyo- $\frac{O}{\mathbb{Q}}$ 
philisations. We are also grateful to Mrs A Veirman for the technical help and to Mrs M Rogghe for preparing the manuscript. This work was supported by the Institute for Hygiene and Epidemiology of the Belgian Ministry of Public Health, contract No G/1701/1983-4.

Requests for reprints to: D Groeseneken, Laboratorium voor Arbeidshygiëne en -toxicologie, Provisorium I, Minderbroedersstraat 17, B-3000 Leuven, Belgium.

\section{References}

${ }^{1}$ Rowe VK, Wolf MA. Derivatives of glycols. In: Clayton GD, Clayton FE, eds. Patty's industrial hygiene and toxicology. 3rd rev. New York: Wiley, 1982:2C, 3909-4052.

${ }^{2}$ Hutson DH, Pickering BA. The metabolism of isopropyl oxitol in rat and dog. Xenobiotica 1971;1:105-19.
${ }^{3}$ Jönsson AK, Steen G. n-Butoxyacetic acid, a urinary metabolite from inhaled n-butoxyethanol (butylcellosolve). Acta Pharmacol Toxicol 1978;42:354-6.

4 Jönsson AK, Pedersen J, Steen G. Ethoxyacetic acid and Nethoxyacetylglycine: metabolites of ethoxyethanol (ethylcellosolve) in rats. Acta Pharmacol Toxicol 1982;50:358-62.

${ }^{5}$ Miller RR, Hermann EA, Langvardt PW, McKenna MJ, Schwetz BA. Comparative metabolism and disposition of ethylene glycol monomethyl ether and propylene glycol monomethyl ether in male rates. Toxicol Appl Pharmacol 1983;67:229-37.

${ }^{6}$ Miller RR, Carreon RE, Young JT, McKenna MJ. Toxicity of methoxyacetic acid in rats. Fund Appl Toxicol 1982;2:158-60.

${ }^{7}$ Fales HM, Jaouni TM, Babashak JF. Simple device for preparing etheral diazomethane without resorting to codistillation. Anal Chem 1973;45:2302-3.

${ }^{8}$ Dermer OC, Dermer VH. Identification of organic acids by partition between ethyl ether and water. Journal of the American Chemical Society 1943;65:1653-4.

${ }^{9}$ Threshold limit values for chemical substances in the work environment. Adapted by the American Conference of Governmental Industrial Hygienists for 1984-5.

${ }^{10}$ Veulemans H, Masschelein R. Experimental human exposure to toluene. I. Factors influencing the invidual respiratory uptake and elimination. Int Arch Occup Environ Health 1978;42:91-103.

\section{Vancouver style}

All manuscripts submitted to the $B r J$ Ind Med should conform to the uniform requirements for manuscripts submitted to biomedical journals (known as the Vancouver style).

The $\mathrm{Br} J$ Ind Med, together with many other international biomedical journals, has agreed to accept articles prepared in accordance with the Vancouver style. The style (described in full in $\mathrm{Br}$ Med J, 24 February 1979, p 532) is intended to standardise requirements for authors.

References should be numbered consecutively in the order in which they are first mentioned in the text by Arabic numerals above the line on each occasion the reference is cited (Manson' confirmed other reports ${ }^{2-5} \ldots$.). In future references to papers submitted to the $B r J$ Ind Med should include: the names of all authors if there are six or less or, if there are more, the first three followed by $e t$ al; the title of journal articles or book chapters; the titles of journals abbreviated according to the style of Index Medicus; and the first and final page numbers of the article or chapter.

Examples of common forms of references are:

' International Steering Committee of Medical Editors. Uniform requirements for manuscripts submitted to biomedical journals. Br Med J 1979; 1:532-5.

${ }^{2}$ Soter NA, Wasserman SI, Austen KF. Cold urticaria: release into the circulation of histamine and eosinophil chemotactic factor of anaphylaxis during cold challenge. $N$ Engl $J$ Med 1976;294:687-90.

${ }^{3}$ Weinstein L, Swartz MN. Pathogenic properties of invading micro-organisms. In: Sodeman WA Jr, Sodeman WA, eds. Pathologic physiology: mechanisms of disease. Philadelphia: W B Saunders, 1974:457-72. 